\title{
Obituary
}

Str Robert Carlyle, k.c.s.I., c.I.e.

$A^{\text {LTHOUGH even now natural science finds }}$ $A$ no place as a compulsory subject in the competitive examinations for the higher ranks of the public service, nevertheless the Indian Civil Service has often included in its ranks a few staunch supporters of the man of science. In this select band the late Sir Robert Warrand Carlyle, a kinsman of the 'sage of Chelsea', whose death in his seventy-fourth year occurred at Florence on May 23 last, takes an honoured place. Four years ago he was seriously injured by a motorlorry in Essex, an accident which was followed by repeated attacks of pernicious anæmia which even his robust constitution could not long withstand.

Educated at the University of Glasgow and Balliol College, Oxford, Carlyle passed the Indian Civil Service Examination in 1878 and was duly posted to Bengal. In 1894 he reached the rank of magistrate and collector and served for many years in the District of Darbhangha, in which in 1904 Lord Curzon founded the Pusa Agricultural Research Institute. After eight years' service as a district officer he was called to headquarters at Calcutta, first as Inspector General of Police and then as Chief Secretary to the Government of Bengal.

In 1907 Carlyle was selected for service under the Government of India as Secretary to the Department of Revenue and Agriculture, and for the next three years came in the closest touch with most of the scientific workers employed by the Central Government, both administratively and also as chairman of the Board of Scientific Advice.

With characteristic thoroughness, Carlyle applied himself to a close study of these somewhat unfamiliar activities, and also made a point of getting into personal touch with the workers themselves. In this latter task he was greatly assisted by Lady Carlyle, who took a deep personal interest in her husband's work and freely devoted her great social gifts to the entertainment of a constant stream of official visitors, many of whom were connected with some branch of science. After three years' service as Secretary, Carlyle was promoted in 1910 to a seat in the Viceroy's Council, his charge including the Department of Revenue and Agriculture and also the Public Works portfolio, an appointment he held until his retirement in 1915 .

Carlyle was thus closely connected with the scientific activities of the Government of India for an unbroken period of eight years, during which he was particularly interested in agricultural research. He was a great friend to the Pusa Research Institute, which he visited on many occasions, and he also found time to attend the meetings of the Board of Agriculture. Under his fostering care the Institute developed with great rapidity : the workers were constantly encouraged to give of their best. The agricultural departments in the provinces were not forgotten. Large sums of money were placed at their disposal for extensive seed farms for the production of pure seed of the new varieties of wheat created at Pusa and at other centres. A new cane-breeding station was founded in South India at Coimbatore.

Carlyle did much to foster and promote the co-operative credit movement and to bring about effective liaison between its officers and those of the agricultural departments working in the Districts. Other interests included the encouragement of the Indian Science Congress, the meetings of which his officers were permitted to attend while on duty, and at which they were given the greatest freedom in the reading ard discussion of papers. Carlyle was always insistent that the scientific workers under the Government of India should look upon themselves as free and independent investigators and not as members of a bureaucracy.

The well-being of agricultural research and the development of the co-operative credit movement were only two of Carlyle's interests. He did much to encourage the scientific study of forestry; he took a deep interest in the Survey of India and in the planning of New Delhi. In these and other similar activities, the scientific workers concerned always found in him a sympathetic and responsive chief and one who spared no pains to understand their point of view and to make them feel that, so far as in him lay, they could rely on getting a square deal.

\section{DR. J. D. GImLette}

Dr. John Desmond Gimlette, whose death on April 24 we regret to record, was born on February 28, 1867. After gaining medical qualifications (M.R.C.S., L.R.C.P., London), as from St. Thomas' Hospital, he at first designed entering practice in the English colony at Lisbon. Later he joined the medical service of the Federated Malay States (Selangor, Perak and Pahang), eventually becoming Residency surgeon for Kelantan and Kota Bahru.

In Malaya, Dr. Gimlette soon became interested in native medicaments and poisons, a subject which occupied him up to the end. In Kelantan, a region little tainted by Western influences, his opportunities were enhanced by innate knowledge of the language and by the confidence which his frank and sympathetic nature impressed on the Malay. Jealous in regard to native secrets, they allowed him to witness, for example, mysteries such as those of Main Peteri, which are recounted in his work "Malay Poisons and Charm Cures" (Third edition, 1929. London: Churchill).

Though much had been done botanically by Ridley, Burkhill, the workers at Buitenzorg 
amongst others, by his medical knowledge Dr. Gimlette was to forge a link between the plant as such and as a drug. A happy collaboration with Mr. I. H. Burkhill led to the publication of a translation of the "Malay Book of Medicine" by Inche Ismail (Gardens Bulletin, Singapore, 6, $1930)$; to this is appended a 'catalogue raisonnée' of very great value. Thereafter, in conjunction with Messrs. Skeat and Thomson, he started on a more comprehensive and ambitious work to be entitled 'The Malayan Medical Dictionary'. This work, though more than half done, is interrupted by his death; however, it is hoped that his collaborators will be able to complete it without undue delay. He was also the author of many minor contributions on medical subjects. During the War he was in charge of a hospital ship (Essiquibo).

From his retirement from active service, Dr. Gimlette was condemned to a sedentary life through the unfortunate loss of a leg from intense erysipelatous infection, but he stuck to his selfimposed tasks with courage and pertinacity. With the cardinal virtues of sincerity and thoroughness, no more loyal or lovable friend could be found, and there are very many who mourn his loss, whilst admiring his constancy of purpose in good and in failing health, though withal cheerful and of good heart.

A final note of sympathy must be struck for his devoted widow, two small daughters, his sisters and other relatives.

H. E. DURHAM.

WE regret to announce the following deaths :

Dr. E. W. Nelson, chief of the U.S. Federal Bureau of Biological Survey, known for his work on the birds and mammals of North and Central America, on May 19, aged seventy-nine years.

Sir Walter P. Buchanan-Riddell, Bt., principal of Hertford College, Oxford, in 1922-29, chairman of the University Grants Committee, on June 5, aged fifty-five years.

Mr. J. J. Fahie, author of several standard volumes on the life and work of Galileo, on June 12, aged eighty-seven years.

Maj.-Gen. George O. Squier, K.C.M.G., member of the U.S. National Academy of Sciences, known for his work in connexion with electrical communications, on March 24, aged sixty-nine years.

\section{News and Views}

\section{International Conference on Physics}

A meetring of the International Union of Pure and Applied Physics will be held in October next in London and a joint conference will be held with the Physical Society, under the presidencies of Prof. R. A. Millikan and Lord Rayleigh. The last meeting of the Union took place in 1931 at Brussels (see NATURE of September 19, 1931, p. 485), when an invitation from the Royal Society to meet in London was withdrawn in order to enable the Union to accept the American invitation for a meeting at Chicago at the Century of Progress Exhibition in 1933. Prof. R. A. Millikan was elected president, but on account of economic conditions the meeting was cancelled and the Royal Society renewed its invitation to meet in London. The invitation was accepted and the meeting will be held on October 1-6. The work of the Union will include consideration of the report of the Commission on Symbols, Units and Nomenclature appointed at its last meeting. The Commission, under the chairmanship of Sir Richard Glazebrook, has dealt with electrical, calorimetric and thermometric units and work has also been done in connexion with radiometric and acoustical units. Dr. Hales' committee on Instruments and Instrumental Methods will, it is anticipated, desire to consult the Union on a number of questions. Apart from this formal business, it was felt that the occasion should also be utilised for international discussion on a subject or subjects now attracting general interest; certain aspects of the solid state of matter were suggested as suitable.

THE Physical Society had already decided to hold a Conference on Nuclear Physics and it was agreed to combine the two proposals. Thus the meeting will take the form of an International Conference, on the joint invitation of the International Union and the Physical Society, under the presidencies of Prof. Millikan and Lord Rayleigh; the details are being arranged by a committee representing the two bodies. The discussion on nuclear physics will be opened by Lord Rutherford with a general survey of the subject. Subsequent papers will deal with cosmic radiation, $\beta$-ray transformation of radioactive elements, artificial transmutations by $\alpha$-rays, neutrons, protons and diplons and new types of radioactivity, and the constitution of atomic nuclei. Sir William Bragg will deliver an opening survey in the discussion on the theory of the solid state of matter. Papers on interatomic forces will be divided into three groups dealing with electrovalent linkings, covalent linkings and van der Waals attractions; as special consideration will be given to the action of these forces in metals at the Aberdeen meeting of the British Association, this particular section of the subjects will not be so fully considered at this discussion. Another group of papers will deal with the possible existence of a secondary structure in crystals, coarser than the fine structure detected by $\mathrm{X}$-rays, and its relation to physical properties. The names of delegates of national unions adhering to the International Union of Physics should be sent to the secretaries of the Conference not later than August 1. Invitations are being sent to a number of physicists known to be interested in these subjects; others desiring to attend should send in their names not later than September 1. All communications should be addressed to the Secretaries, International Conference on Physics, Royal Society, Burlington House, London, W.1. 